\title{
National Examination in Indonesia and Its Backwash Effects: Teachers' Perspectives
}

\author{
Velentina Rizki Sutari \\ Universitas Pendidikan Indonesia, Bandung \\ velentinars@gmail.com
}

\begin{abstract}
The change of national examination's status from high-stake testing, of which backwash has a greater impact, to low-stake testing, influences the practice of teaching and learning of English. This study is geared toward investigating teachers' perspectives on national examination and unearthing how it influences the way teachers give their instructions. Using qualitative descriptive method and interview to gain the data, the findings show that a private school teacher has a negative perspective on national examination. Meanwhile, a teacher teaching at language course has a relatively neutral attitude toward national examination. Their perspectives influence the way they teach English at their institutions. The private school teacher teaches English based on students' needs. However, in teaching $9^{\text {th }}$ graders, she teaches her students how to answer English questions in national examination. Likewise, the language course teacher teaches her students how to answer English questions in national examination. Thus, it is recommended for the test makers to be wiser in determining what kind of test that can cover all English skills.
\end{abstract}

Keywords: National Examination, High-Stake Testing and LowStakeTesting Teacher' Perspectives

\section{INTRODUCTION}

National examination or Ujian Nasional (UN) was considered as a high-stake testing, meaning that this test was decided to be the main and only consideration in students' admittance to the higher education level (Saukah, 2015). National Examination has been implemented since 2003 when the Minister of National Education, for the first time, launched the decree Education No. 153/U/2003, 14 October 2003 concerning National Examinations (henceforth UN Ujian Nasional) for the academic year 2003/2004 (Sulistyo, 2009).

The new policy regarding this issue changes the national examination's status from high-stake testing to low-stake testing, meaning that student's admittance to the higher education level is determined by the authority at schools based on students' academic achievement at schools (Saukah \& Cahyono, 2015). National examinationis now implemented as a basis of (1) map of the quality of education of instructional program, (2) consider selection purposes of for the next levels of education, and (3) plan some corrective action and funding schemes to support the improvement of the quality of education at schools and district levels (Saukah \& Cahyono, 2015 , p. 244). However this implementation of national examination and its status still cause controversies (Saukah, 2015).

Those who support the implementation of national examination argue that national examination needs to be administered since it can motivate the students to study seriously. Without it, the students will think that they can graduate eventually and they do not have to study seriously. The second argument deals with the comparison of students' competencies. The last one is without national examination. The school officials are the ones deciding whether students can graduate or not. However, there is a concern that the school officials will let their students graduate regardless whether or not they have achieved the required competencies (Saukah, 2013, cited in Saukah, 2015).

In contrast, for those who are against national examination argue that (1) using national examination to be the main consideration in students' admittance to the higher education level is not fair since the schools throughout Indonesia are still very heterogeneous, (2) national examination may bring negative backwash on the implementation of the curriculum leading to its reduction to test-coaching or teaching-to-the-test, and (3) since national examination's status is a high-stake testing which means it involves all schools throughout the country, it needs a very complex management which causes the ignorance of the testtakers and stake-holders (Saukah, 2015).

Despite the change of its status from high-stake testing to low-stake testing, national examination, as any other tests, may bring backwash-positive or negative. One of the concerns about one of negative backwash mentioned by Saukah (2005) is the implementation of the curriculum leading to its reduction to test-coaching or teaching-to-the-test. National examination includes English subject to be tested to the $9^{\text {th }}$ graders of junior high school and $12^{\text {th }}$ graders of senior high school. Teachers at school sometimes coach or do teachto-the-test to their students. As the result, students tend to focus on answering the questions correctly instead of using English as a language (Zubaidi, 2014). Furthermore, Zubaidi (2014) states that national examination only focuses on the passive aspects of English using and it forces the students to learn to memorize the answers.

The related studiesthat examine national examinationand its backwash come from Sulistyo (2009), Sukyadi and Mardiani (2011), Zubaidi (2014), and Saukah (2015).Sulistyo (2009) tries to analyze English teacher's point of view, as frontline agents in the field, with its relation to the issues concerning national examination. This study reveals that in spite of the teachers' positive point of view, when challenged to accepting the responsibility in the context of classroombased-assessment as a part of their autonomous roles, they demonstrate an impression of disinclination (Sulistyo, 2009). 
Another study by Sukyadi and Mardini (2011) indicates that teachers and students involved have different perception towards national examination. The study also shows that national examination also has the big influential impact on teachers' teaching in the aspect of activity/time arrangement, teaching materials, teaching contents, teaching methods, teaching strategies, ways of assessing, and on the feelings and attitudes of the students (Sukyadi \& Mardini, 2011). Furthermore, study conducted by Zubaidi (2014) scrutinizes the student's perception towards ideal vs. practice of Indonesian senior high school national examination of English subject. The findings of the study uncover that $97 \%$ of the respondents show strong objection on the idea of national examination as a means of graduation (Zubaidi, 2014). In the recent study, Saukah (2015) investigates the implementation of the National Examination and how it affects different aspects of education in Indonesia by taking into account the ever-changing nature of the policies issued by the Ministry of Education and Culture. The study finds that even though the government has changed the national examination function not as the basis of students' graduation decision-making, it is still considered to be a high-stakes testing since it is used as a main consideration in students' admittance to the higher education level.

It is clear that national examination is still a controversy among academics and Indonesian public. This study, therefore, is aimed at investigating the perspectives of a teacher teaching at one of private schools and a teacher teaching at one of language courses and the way they teach English with its relation to national examination. The purpose is to provide a space for these teachers as the frontline agents in the field to voice their take on national examination.

\section{METHOD}

To achieve this purpose, qualitative method is employed. The respondents involved in this study are two English teachers from two different institutions. One teaches in a private school, while the other at an English language course center. Both are teaching junior high school level. The teachers are deemed fit to be the respondents due to their experience in teaching English in their respective institutions.The data were collected through a structured interview session with each respondent.

\section{FINDINGS AND DISCUSSION}

The teacher teaching at a private school states that national examination is useless since (1) it is such a waste of money, (2) it does not give any significant effect to betterment of education, and (3) it gives more disadvantages than advantages. One of disadvantages is students and schools, even, will do unfair action. Furthermore, students will feel more stressful in doing the national examination.

On the other hand, the teacher teaching at a language course gives a neutral definition towards national examination. She states that national examination is a test conducted by our (Indonesian) government to standardize our (Indonesian) students' qualification of education. From this statement, therefore, national examination's purpose is to standardize the students' qualification of education.

Concerning the status of national examination, the teacher teaching at the language course argues that national examination can be considered as high-stake testing since it is able determine students' fate, whether they can graduate from their school. Besides, it is also risky since the government applies the same standard to all students in Indonesia whose background, resource, and competence are different. Likewise, the teacher teaching at private school also points out that national examination is used as the requirement for the students whether they can continue to the higher level. However, she adds, national examination is not a high-stake testing anymore meaning that its status already changes to low-stake testing.

In terms of the way both teachers teach English in their institutions, the teacher teaching at private school says that the teaching method for $7^{\text {th }}, 8^{\text {th }}$, and $9^{\text {th }}$ grade is different from one to another. She mentions that she teaches English as a means of communication in $7^{\text {th }}$ and $8^{\text {th }}$ grade only. She focuses on the students' English ability both in written and spoken skills. However, it is a different story when she teaches $9^{\text {th }}$ graders, she only teaches the materials that will be tested in national examination. Likewise, the teacher teaching at language course also teaches the students based on their needs of national examination. Therefore, she only uses the materials that are basically derived from national examination test items. She further states that it is hard to teach English communicatively since she only focuses on texts. She only gives the students a lot of exercises in the form of text types questions, grammar rules related to it, and sometimes she has to give extra time for those who are still in need of explanation on how to do the national examination. As a result, it affects the way she teaches English.

Both teachers do not change the way they teach English at their institutions. They still focus on how to answer the test items in national examination. One of the teacher even states that it is really hard for her to teach English as a means of communication since she has to meet the students' needs; to pass the test. Despite its changing status, it does not really give significant influence to the way these teachers teach English. As a result, the negative backwash that this test brings still remains.

\subsection{INTERPRETATION TO THE FINDINGS}

As stated earlier that national examination may bring negative backwash which is teachers tend to teach how to answer English questions correctly in the test than teach English as a language. This statement seems to be followed by both teachers who state that they teach English based on what is needed in the national examination instead of teaching English as a means of communication. Hughes (2003) gives his concern regarding this situation. Since the test technique in national examination, particularly for English subject, is multiple choice, Hughes (2003, p. 78) argues that "there is a danger that practice for the test will have a harmful effect on teaching and learning - the attention is paid to improving 
one's educated guessing the content of the items." This is not the best way for students to improve their command of a language (ibid.).

This negative backwash of national examination brings is caused by its status as a high-stake testing. Thus, the government makes a new policy that changes the status of national examination from a high-stake testing to a low-stake testing. However, the result of the study conducted by Saukah and Cahyono (2015, p. 253) shows that "in the response to the finding on how English teachers teach their students to prepare national examination when the status is as a high-stake test and a low-stake test, it seems that those high-achieving schools are not affected by the change of national examination's status." This is in line with the respondents in this study who state that the change of the status of national examination does not affect the way they teach English, instead, they still teach how to answer the English questions correctly by giving the students more and more national examination-exercise-like.

\section{CONCLUSION}

The change of national examination's status from highstake testing to low-stake testing does not affect that much to the way the respondents teach English. Teachers still believe that national examination is the most important test that students need to pass. Therefore, this perspective affects the way they teach English. They have this assumption that students' need is passing the examination, thus, it guides these teachers to the way they teach English to their students. This negative backwash that national examination brings is not supposed to be the reason that government should stop administering the national examination. The test-maker, in this case, should take many considerations in making such test, for example, the result of English test of the national examination could not be used to determine students' fate in continuing their education. Also, the examination, for practical reasons, is supposed to include not only receptive skills but also productive skills because English is not only listening and reading but also speaking and writing.

\section{REFERENCES}

Hughes, A. (2003). Testing for language teachers. Cambridge: Cambridge University Press. Developing Indigenous Models of English Language Teaching and Assessment. Edited by Hamied, F.A., I.B.P. Yadnya, and I.G.A.G. Sosiowati, 143-160. Denpasar, Bali: Udayana University Press.

Saukah, A. (2015). National Examination in Indonesia and Its Washback Effects. In Developing Indigenous Models of English Language Teaching and Assessment. Edited by Hamied, F.A., I.B.P. Yadnya, and I.G.A.G. Sosiowati, 143-160. Denpasar, Bali: Udayana University Press.

Saukah, A., \& Cahyono, A. E. (2015). Ujian Nasional di Indonesia dan Implikasinya Terhadap Pembelajaran Bahasa Inggris. Jurnal Penelitian Dan Evaluasi Pendidikan,19, 2nd ser., 243-255. Retrieved April 26, 2016.

Sukyadi, D., \& Mardiani, R. (2011). The Washback Effect of the English National Examination (ENE) on English Teachers' Classroom Teaching and Students' Learning. K@ta,13(1), 96-111. Retrieved April 26, 2016.

Zubaidi, N. (2014). Ideal vs Practice of Indonesian Senior High School National Examination of English Subject: Students' Perception. Retrieved April 25, 2016, from http://www.academia.edu/7463607/Ideal_vs_Practice_of _Indonesian_Senior_High_School_National_Examinatio n_of_English_Subject_Students_Perception. Unpublished Article

Sulistyo, G. H. (2009). English as a Measurement Standard in the National Examination: Some Grassroots' Voice. TEFLIN Journal,20(1), 1-23. Retrieved April 26, 2016. 